\title{
Eletriptan provides consistent migraine relief: results of a within-patient multiple-dose study
}

\author{
M Almas ${ }^{1}$, S Tepper ${ }^{2}$, S Landy ${ }^{3}$, E Ramos $^{1 *}$ \\ From The European Headache and Migraine Trust International Congress \\ London, UK. 20-23 September 2012
}

\section{Objective}

To evaluate the consistency of response to eletriptan in migraine.

\section{Background}

Surveys indicate that more than $40 \%$ of individuals have an average headache frequency of 2 or more attacks per month. Lack of consistent response has been cited in patient surveys as one of the top 3 reasons for dissatisfaction with migraine treatments.

\section{Methods}

Patients first completed an open-label, lead-in period in which they treated 3 migraine attacks with eletriptan $40 \mathrm{mg}$. Based on response to open-label treatment, patients were treated with either eletriptan $40 \mathrm{mg}(\mathrm{E} 40 ; \mathrm{N}=539)$ or eletriptan $80 \mathrm{mg}(\mathrm{E} 80 ; \mathrm{N}=432)$ in a 4-attack consistency of response study in which placebo was substituted, in a randomized, double-blind fashion, for the treatment of one attack. Headache response was defined as improvement at 2 hours post-dose to a headache intensity of none (pain-free) or mild. Within-patient consistency was defined a priori as headache response at 2 hours on at least 2 out of 3 attacks.

\section{Results}

During double-blind treatment, within-patient consistency was $77 \%$ for $\mathrm{E} 40$ and $73 \%$ for E80. For patients $(\mathrm{N}=47)$ who had responded to $0 / 3$ attacks on $E 40$ in the open-label phase, titration to the E80 dose resulted in headache response in 55\%. A repeated measures logistic regression analysis found that sustained headache response at 24 hours, averaged across 3 attacks, was significantly higher on both E40 vs. placebo (49\% vs. $32 \%$; $\mathrm{p}<0.001)$ and E80 vs. placebo (43\% vs. $11 \%$; p < 0.001$)$. Sustained pain-free at 24 hours, averaged across all 3

${ }^{1}$ Pfizer Inc, USA

Full list of author information is available at the end of the article attacks, was also significantly higher on both E40 vs. placebo ( $30 \%$ vs. $5 \% ; \mathrm{p}<0.001)$ and E80 vs. placebo ( $25 \%$ vs. $3 \%$; $\mathrm{p}<0.001)$.

\section{Conclusion}

Eletriptan showed consistent and sustained efficacy in the treatment of migraine. Funded by Pfizer Inc.

\section{Author details \\ ${ }^{1}$ Pfizer Inc, USA. ${ }^{2}$ Cleveland Clinic, USA. ${ }^{3}$ Wesley Neurology and Headache Clinic, USA.}

Published: 21 February 2013

doi:10.1186/1129-2377-14-S1-P131

Cite this article as: Almas et al:: Eletriptan provides consistent migraine relief: results of a within-patient multiple-dose study. The Journal of Headache and Pain 2013 14(Suppl 1):P131.

\section{SpringerOpen ${ }^{\circ}$}

(c) 2013 Almas et al; licensee Springer. This is an Open Access article distributed under the terms of the Creative Commons Attribution License (http://creativecommons.org/licenses/by/2.0), which permits unrestricted use, distribution, and reproduction in any medium, provided the original work is properly cited.
Submit your manuscript to a SpringerOpen ${ }^{\circ}$ journal and benefit from:

- Convenient online submission

- Rigorous peer review

- Immediate publication on acceptance

- Open access: articles freely available online

- High visibility within the field

- Retaining the copyright to your article

Submit your next manuscript at $>$ springeropen.com 